\title{
(East) African postcolonial ecocriticism: Revisiting Okot p’ Bitek's Song of Prisoner
}

Alex Nelungo Wanjala

\section{(East) African postcolonial ecocriticism: Revisiting Okot p'Bitek's Song of Prisoner}

This article celebrates 0 kot p'Bitek's contribution to East African literature in general and the song school of East Africa in particular, by revisiting one of his less-known works, Song of Prisoner on the fiftieth anniversary of its publication. I subject the text to a close reading in order to demonstrate how p'Bitek uses imagery that is drawn from East Africa's natural environment in a way that evokes issues that are an assault on the prevailing social and political order in East Africa at the time, in a nuanced manner. With the benefit of hindsight, the paper establishes that p'Bitek's attempt to preserve his natural environment (that of East Africa) through writing it into his poetry, was a precursor for texts that would later be examined within the framework of the contemporary critical theory of postcolonial ecocriticism, and that using the text, one can narrow the scope further in a manner that takes into account the specificities of (East) African environmental literature. In so doing, the paper establishes that p'Bitek indeed highlights social realities through his poetry, in order to launch his attack on the existing neo-colonial capitalistic order prevailing at the historical moment of his writing, thus confirming that he displays a social vision that strives for decolonisation without the exploitative aftermath encapsulating modernity. The paper thus demonstrates how this poem is still relevant as a study to the student of East African literature reading it in the $2 \mathrm{l}^{\mathrm{st}}$ century. Keywords: Song School, East African poetry, Okot P'Bitek, postcolonial ecocriticism.

\section{Introduction}

In a 1965 symposium on "East Africa's Cultural Heritage" held in Nairobi, Okot p'Bitek made the following observation "The first step in vernacular literature is not a step. The first step is to open ears. Listen to the birds' songs and the talk of the monkeys" ("Future of the Vernacular Literature" 24). p'Bitek-who had by that time already published two novels in the Acoli language and had been working on the manuscript of his Acoli song Wer pa Lawino (1969), whose translated version Song of Lawino (1966) would be published the year following this symposium - thus highlighted the importance of a writer's being attuned to their natural environment, as one of the key ingredients of vernacular literature from East Africa. Another speaker at the same symposium, Gerald Moore expressed similar sentiments, albeit in regard to literature in English expression coming out of East Africa at the time, by observing that writers such as Jomo Kenyatta, James Ngugi (Ngugi wa Thiong'o), Joe Mutiga, and Jonathan Kariara depicted a feeling of total harmony with their environment in their writing, thus identifying a love of landscape and nature as a hallmark of East African literature.

When one reads p'Bitek's later poetry in English expression, one observes the fact that he carries over his philosophy in regard to the writing of 'vernacular' literature over into those texts, more or less to a discernible degree. Indeed, all critics of p'Bitek's poetry agree that his composition borrows heavily from Acoli orature, thus replicating forms of authentic African poetry in written texts. Nevertheless, scant attention has been paid to how he represents the natural environment through his poetry (the exception being Caminero-Santangelo's study of Song of Lawino and Song of ( col). This may be seen as a blind spot in terms of the study of his oeuvre. A quest to examine the manner in which the natural environment is depicted through p'Bitek's writing thus serves as my entry point in regard to revisiting his poem Song of Prisoner fifty years after its publication.

The poem is one of two songs published by p'Bitek in an anthology titled Two Songs (1971), the other being Song of Malaya. Both poems provide a commentary on East African society a decade after independence and dwell

Alex Nelungo Wanjala is a senior lecturer in the Department of Literature and sub-department of French at the University of Nairobi, Nairobi, Kenya. Email: nelungo@uonbi.ac.ke

(D) https://orcid.org/0000-0002-0609-5982

D0l: https://doi.org/10.17159/tl.v58il.8301

DATES:

Submitted: 18 May 2020; Accepted: 18 February 2021; Published: 25 May 2021 
on issues related to the situation of the urbanite in the early 1970s. Indeed, Okot p'Bitek is well placed to be seen as a regional commentator having moved from Uganda, the country of his birth, to Kenya, in the mid-sixties, and thus incorporating social and political issues from both countries into the writing of his poetry. Thus, Malaya presents the reader with issues related to religion, morality, and prostitution in the developing milieu of East African urban society, while Prisoner highlights social issues in a manner that attacks the existing neo-colonial capitalist social order that was emergent in East Africa at the time.

In a 1981 interview with Lee Nichols for Voice of America, p'Bitek explained how he was once incarcerated in a jail cell after causing a disturbance while on a train ride from Nairobi to Kisumu. With the incident fresh on his mind a week later, he received news about the assassination of a Kenyan cabinet minister, Tom Mboya, whom he regarded as a friend. He was thus inspired to write the poem Song of Prisoner (Nichols 249). Indeed, the assassination of Tom Mboya and the forced silences around the event, marked a turning point in Kenyan history that has been variously described in literature by other writers like Marjorie Oludhe Macgoye and Yvonne Owuor. The fact that thematically, the poem engages in representing the social and political realities of East Africa in the historical period roughly a decade after the independence of East African countries, makes it belong to what Phyllis Taoua describes as part of the growing body of literature in the period immediately after independence, which conveyed a sense of disillusionment with the fact that the dreams of independence had been betrayed, and that the colonial authorities still somehow influenced the corrupt and autocratic regimes that were in place. Thus, in order to take this factor into consideration, the second focal point in my evaluation of the poem will be to subject it to a postcolonial critique, which will demonstrate how p'Bitek uses imagery that is drawn from East Africa's natural environment in a way that evokes thematic issues that are an assault on the prevailing social order in East Africa.

From the foregoing, it becomes evident that in order to take into consideration a presentation of the environment in literature, as well as undertaking a postcolonial critique of the poem under evaluation, my argument would have to be accommodated within the framework of postcolonial ecocriticism. A brief examination of the history of the concept as well as how it should apply to my study is therefore necessary at this point.

As was highlighted at the 1965 symposium mentioned above, a love for nature and the environment has always been part of East Africa's cultural heritage and this was depicted in the literary texts that emerged from the region even in pre-independence times and has been addressed in critical studies of African literature, in one way or the other since then. Concurrently, over the years, and especially since the 1970s, various paradigms of environmental literary criticism have been developed in the Global North that do not really reflect the approaches used by writers from the Global South in their critical evaluation of nature writing from their regions.

These Western approaches are multi-disciplinary since they incorporate the scientific aspect of ecology in literary criticism. They have also privileged the presentation of nature at the expense of a presentation of a history of the impact of modernity on indigenous people and their cultures, as is argued by Caminero-Santangelo and Garth A. Mayers. They also fail to take into account what has been described by Rob Nixon as a "slow violence" which is the invisible aftermath of environmental crises as a result of human activities such as war, and how these crises affect ecosystems, the poor in society, and the world in general.

Therefore, such Western approaches, which eventually crystallised into what was defined by William Rueckert as ecocriticism, were seen to be counterproductive when applied to the analysis of literature from the Global South and indeed to the literature of the minorities in the Global North, because of the fact that they suppressed the histories of the impact of modernity on the indigenous peoples and their cultures in the quest to accommodate ecology within the theoretical paradigm of ecocriticism.

The situation thus led to a counter-reaction by literary critics who desired "to make ecocriticism more responsive to historical relationships of power, to colonial history and its effects and to cultural difference" (Caminero-Santangelo 5). This aspiration to question the historicity of ecology and to address the different cultural understandings of nature within "global imperial contexts" (6) led to the development of postcolonial ecocriticism, which "often emphasizes the similarities between [ecocriticism and postcolonial cultural studies] in terms of a sense of political commitment, interdisciplinarity and the interrogation of capitalist development and progress" (3).

The quest to avoid Euro-American essentialism in the study of ecocriticism by postcolonial critics has led to several book length publications in the contemporary period: a foundational text on postcolonial ecocriticism (Huggan and Tiffin); one that focuses on the nexus between the environment, nature, and history in the Carib- 
bean (Deloughrey, Gosson, and Handley); one that focuses on the environmentalism of the poor in the Global South (Nixon); others focusing specifically on the depiction of the environment in African literature (Moolla); and animal studies in African literature from a posthuman ethics perspective (Mwangi), just to name a few that this article relies upon in its analysis of p'Bitek's poetry.

There are also some seminal articles that focus specifically on African postcolonial ecocriticism. One that will be instrumental to my analysis is Chengyi Coral Wu's "Towards an Ecocriticism in Africa: Literary Aesthetics in African Environmental Literature", which not only echoes Rob Nixon's approach to an environmentalism of the poor, in the South, but also narrows the scope of methods of postcolonial ecocriticism to focus specifically on African studies. She argues that African writers respond to local rather than global issues in their writing of environmental literature by addressing concerns such as "environmentalism for the poor" and issues of "environmental decadence" $(147,148)$. Wu thus suggests a critical methodology in regard to ecocriticism that focuses upon highlighting the complicated nature of environmental issues in African literature, with a focus on environmental justice, as well as a focus on the aesthetics of African environmental literature in a manner that "[pays] attention to African environmental imaginations, as revealed in African literary productions [in order to] recognize indigenous African environmentalisms and avoid misconceptions or oversimplifications that ignore the possibility of resistance or the existence of an agency, or a local-based environmentalism" (159).

Such an approach allows for accommodating the idiosyncrasies arising from historical, social, and ethical issues directly related to a specific locality or region. It also allows the critic to focus on a specific text's aesthetic merit. Indeed, such peculiarity is recommended by Elleke Boehmer, who in her call for rerouting postcolonial studies advocates a "postcolonial aesthetic" that links the postcolonial and historical elements in a work of art with the language of postcolonial writing. My paper will thus focus on a critical evaluation of the form of p'Bitek's writing, without however losing sight of the ideology in his writing. My approach entails examining p'Bitek's work using a universal framework of literary analysis, that however leads to an interpretation which is culturally specific and also related to a specific ideology in regard to the historical period in which the work is composed. My approach to postcolonial ecocriticism will thus oscillate between the examination of form and content in an analysis of Song of Prisoner.

\section{Content and aesthetics in Song of Prisoner}

The organisation of Song of Prisoner is straightforward. It is divided into fifteen sections, each with a heading that symbolically represents the theme that will be addressed within that particular section. Some examples of these titles as such as "dung of chicken", "soft grass", and "oasis". Therefore, in a manner of speaking, one could argue that the poem uses imagery even from the titles of these sections in a way that would guide the reader in regard to what to expect as they move along with their reading of the song. Another significant element of the titles is that they are all drawn from images that are related to a pre-colonial, natural, and rural ecosystem, which are shown to have been undisturbed by modernity and conserved in a kind of pristine state.

This is in sharp contrast with the setting of the poem which is in one of the harshest settings one could come across: an urban prison, one that is located in one of East Africa's capital cities, given the crimes that the prisoners are charged with. The use of contrast leads the reader to identify the text as being on that is located at the edge of two ecosystems: that of the natural rural habitat displaying a pristine past, and that of the man-made urban jail, an unnatural and uncomfortable habitat which relates to the present. The dialectics in the use of contrast in the poem thus depicts an ecotone, through a display of the tension between urban and rural ecosystems within the text. This display of formal resistance in the composition of the poem, indicates a kind of yearning for change within the established social order, a yeaning that is expressed not only through the content, but the aesthetics of the poem.

Imagery through metaphor thus serves as a key ingredient to the understanding of the meaning of the poem. Adrian Roscoe's observation on p'Bitek's writing in regard to Lawino, still holds true if applied to a reading of Prisoner: "Okot [...] flies straight to the home scene for his imagery without stopovers in Europe, as he must do if his 
work is to be authentic and persuasive to a local audience" (44). This becomes evident when one examines how p'Bitek uses metaphors in Prisoner. Beverly Mack states in regard to her study of Hausa poetry:

Metaphor has been recognized since the time of Aristotle as a supreme form of figurative speech. It is the most effective means of imbuing a poem with meaning. Terminology for the elements of a metaphor distinguishes between the bearer of the image, or "vehicle", and the implied image, the "tenor" [...]. The vehicle is the set of words that creates an image, while the tenor is its implied meaning. (44)

I intend to use the above definition of metaphor in my study in order to signal the vehicle and tenor in relation to the nature imagery used in Prisoner as a means of explaining and illuminating the meaning of the poem. As Stuart C. Brown explains in regard to the use of metaphor and rhetoric as an instrument used in understanding meaning, "Awareness of the tenor/vehicle interaction, comparison and context are the key elements in using this instrument. They provide the composition or grounds for the meaning-making potential of the metaphor" (227). It is with this in mind that my analysis will endeavour to provide context to the meaning derived from the nature imagery used in the poem, drawing from intratextual and extratextual references.

Anthony Vital puts the same into practice through an appreciation of the social and historical dimensions of discourse in his reading of J. M. Coetzee's Life $\sim$ Times of Michael K (1983). Vital comments on how the significance of nature in Coetzee's novel does not arise from an ecological perspective, but rather from interrogating the novel's textuality. He highlights the interplay between the realist and metafictional planes of the novel, which when juxtaposed with the natural world as is written into the narrative, reveals how the social and political conditions in a specific period of South Africa's history respond to a modernity rooted in colonialism and its attendant flows of power. According to Vital in his analysis of the novel, "the novel's writing of nature is subordinate to its profound suspicion of modernity, and [...] as a result its assigning of value to nature reproduces the terms of a broadly conceived 'romantic' discourse" (96). Vital thus advocates and applies a postcolonial ecocriticism that is suited to local conditions in Southern Africa.

My article draws from his analysis as applies to East Africa, in order to demonstrate how nature imagery is used in the poem to obfuscate a realistic presentation of the social and political situation of East Africa in the late sixties, and that the imagery, when juxtaposed with the extratextual elements of the text, reveals the implied meaning of the text, which relates to p'Bitek's condemnation of modernity through his presentation of the effects of neo-colonialism and his attendant desire for a revolution that would rid East African society of those adverse effects.

Finally, over the years since its publication, the analysis of Song of Prisoner has always been subsumed under that of p'Bitek's other poems, where it is examined alongside one or the other, and very briefly at that. This has led to a certain confusion in regard to the meaning of the poem and also in regard to some of its basic features such as the number of persona(e) depicted in the poem. My revisiting of the poem intends to undertake a sustained reading of the same, and through this close reading demonstrate how this text is still relevant to East African society in the $21^{\text {st }}$ Century.

\section{The vagrant and the slow violence of environmental degradation in East Africa}

The poem opens with a section titled "dung of chicken". The terminology used symbolically represents something that is worthless, as chicken dung has no practical use within the East African rural environment, and is normally simply swept away and discarded, unlike, say cow dung which would be used to smear the floor of a house, seal baskets that will be used to store grains and flour, and other such practical purposes. The imagery used in the title thus guides the reader to an awareness of the fact that the content of the section will address the characteristics 
of worthlessness in society. This indeed becomes evident as we read through the section. It begins with a description of the environment in which the persona finds himself at the present moment. The scene is described thus:

The stone floor

Lifts her powerful arms

In cold embrace

To welcome me

As I sit on her navel

My head rests

On her flat

Whitewashed breasts

She kisses

My bosom

My neck

My bellybutton

My back

My buttocks

And shoots freezing bullets

Through my bones. $(11,12)$

The prison floor is personified as a woman who has invited the prisoner into her cold embrace. The poet gives a detailed description of the discomfort felt by the prisoner in the cell, through describing all the body parts affected by the cold. This emphasises the hostility of the prisoner's immediate environment, an urban prison. The prison here could be said to be a symbol of modernity as it is part of the institutions that were introduced in Africa as part of the Western penal system. The prisoner's incarceration in this environment is painful and foreign to him and the helplessness he feels is demonstrated when he is asked to take his plea:
Do you plead
Guilty
Or
Not guilty?
I plead drunkenness,
I am intoxicated
With anger
My fury
Is white hot
My brain is melting
My throat is on fire
I am dizzy
With frustration
I am drowning
In the deep Lake
Of hatred
My heart is riddled
With the arrows
Of despair
My head is bursting
Oh! $(12,13)$

The use of nature imagery through the use of conceit in reference to the "deep lake of hatred" in which the prisoner is drowning, emphasises the fact that the prisoner is frustrated by the system that has led to his incarceration. Other metaphors are also used to describe the emotions that he is undergoing due to the seemingly unjust treatment he is receiving.

The frustration of the present moment is contrasted with the past. Through the use of rhetorical questions, the prisoner indicates how in the past he was useful to society, unlike in his present circumstances. He describes 
how he participated in several sporting activities such as football, boxing, wrestling, running, and hunting. The prisoner reminisces about this as he wonders why his gaolers are now inflicting wounds on his body.

Look at the laughing wound

In my head

Its cracked negro lips

Painted with dirty brown ochre

Do you see

The beads of blood

On my nose and feet?

My nose

Is a broken dam

Youthful blood leaps

Like a cheetah

After a duiker

Two fingers

The width of the new gap

In my teeth ...

The metaphors used to describe the wounds inflicted on the prisoner through overt violence in the jail cell, are paradoxically delivered through a description of capture of rural landscapes that are presented to the reader using vivid colours and a description of the natural resources found within that ecosystem such as dams. The poet then juxtaposes the illustration with zoomorphic imagery that presents activities that would take place within a Savannah grasslands ecosystem.

The meaning of the verse could thus be captured through an understanding of the irony evident in these images, in that what should be a beautiful scene is actually fraught with danger. The animals pictured are engaged in a hunt, while the dam described has broken its banks. Through detecting the use of irony, the reader establishes the dialectics between the past and the present at play, and thus arrives at understanding how imagery functions to give meaning in the verse. What at face value is a portrait of a beautiful scene in nature, actually describes a present scenario in which the prisoner's face is injured, and he is bleeding profusely.

The images of nature as used also present the idea of the nostalgia that the prisoner has for the wide-open spaces which he describes, while in captivity. The contrast between them and the present surroundings of the prisoner reinforces the fact that the past was more pristine than the present moment. The rural area as contrasted with the urban area, reveals the beauty of the former as compared to the desolation of the latter, demonstrating how the writer displays a certain attachment to the rural environment which by extension reveals that the past was better than the present. This pastoral quality is a motif that is indeed employed throughout the poem. The meaning of the title of the section "dung of chicken" has by now become evident. It indicates that the prisoner feels that his present circumstances have rendered him useless, and that this is due to his poverty and social position. He describes this using imagery.

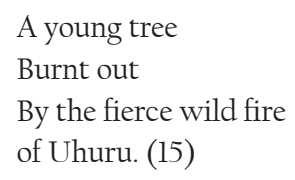

The image presented above is that of a young tree that had the potential for a bright future were it allowed to grow tall. It however had its growth cut short by a wildfire, as often happens in forests during the dry season. This wildfire is likened to the economic situation faced by a large number of people after the independence of East African countries. At independence, the youth found themselves in a situation in which they lacked employment or business opportunities. This extended metaphor thus uses nature imagery to bring out the idea that the young man finds himself alienated from society in the post-independence period. Whereas there are people around him that may have benefitted from Uhuru (a Swahili word meaning "freedom"), or independence, he feels like he is one of those that have no place in the new society, and is being punished simply for his existence, hence his fury. p'Bitek through this image is indicating the feeling of dispossession by a large section of the populace in East Af- 
rica represented by this prisoner, who is thus depicted as belonging to the economically disadvantaged category of people in that society.

The image of the destruction of nature through calamities like wildfires is an ecological referent that reveals what Rob Nixon has described as "slow violence": "a violence that occurs gradually and out of sight, a violence of delayed destruction that is dispersed across time a space, an attritional violence that is typically not viewed as violence at all" (2). The ecological effects of a fierce fire that burns out a tree, or a forest for that matter, would not be immediate, but gradual, as the destruction of trees leads to calamities that are linked to deforestation such as reduced rainfall and food scarcity for communities that depend on adequate rainfall for their food security as is the case for a large section of East Africa. Through the use of nature imagery, p'Bitek is therefore indicating the slow violence that a large section of the youth in East Africa were subjected to during the decolonisation and subsequent period in regard to their economic development, leading to an increase in poverty in the post-colonial period.

Indeed, Frank Girling describes how there is geological evidence that the larger area in which Acoliland is situated started out as what was probably a semi-arid area, but with adequate rainfall became more favourable for habitation, leading to large groups of Nilotic speakers moving into the region, including the Acoli. Over time, however, the environment suffered from pressure due to the numbers of pastoralists depending on the vegetation from the area, hunting methods engaged in by the Acoli which involved burning of grass, clearing of the forests for building materials, the decimation of Acoli cattle herds by Sudanese slave traders, and the establishment of British rule in the area, all contributing to the fact that by 1950's when Girling conducted his research in the area of the Northern Province mountains in which Acoliland is situated, the area was deforested and more or less deserted $(80-4)$.

The prisoner questions his gaolers on the reasons for his arrest through posing some rhetorical questions. He mentions a few crimes that probably would have justified the fury of the prison guards against him, had he committed them. These are such as being a night runner caught dancing outside one's house, a man who has been caught in bed with another man's wife, or one who has raped another man's mother. Such crimes that would evidently drive the victims to anger and brutality, are compared with the actual crime that has led to the prisoner's incarceration and the subsequent physical violence of which he is a victim. By using satire to contrast the imagined crimes with the actual crime, the author reveals to the reader just how unjustly this prisoner feels he is being treated, and by extension gives a commentary on the nature of the present-day justice system and how unfair it is to the citizenry, especially the poor, through revealing that the prisoner has been arrested for vagrancy.

Why should I not

Sleep with the green grass

In the City Park

While I nurse

My hunger?

Why do they call me

A vagrant

A loiterer? $(15,16)$

The image of the green grass in the city park illustrates a haven of peace and comfort in an otherwise hostile urban setting, that would provide some form of relaxation and relief to all residents within the city. However, the prisoner who was forced by colonial violence to move to the city, is subjected to further trauma when he loses his personal freedom by being arrested for vagrancy while trying to forget his problems by relaxing in the city park. p'Bitek, through the vagrant, highlights issues of environmental and social justice in East African society during his time. While describing urban landscapes without focusing on spaces such as sprawling slums in urban areas, as has been done by various authors addressing the question of poverty in East Africa, p'Bitek uses his spatial imagination in a manner that describes the experience of loss felt by the masses due to capitalism and neo-colonialism. He depicts a situation that has emerged in East Africa in which a large section of the populace that lives in urban areas lacks access to public utilities and resources due to their economic and social status.

The partitioning of urban green spaces in a manner that locks out the poor, is another instance of the slow violence that the masses are facing even during the postcolonial period. This environmental segregation belies the dreams of equality envisaged during the struggle for independence, as the vagrancy act, as is described by 
Akutekha was indeed applied selectively by law enforcement officers to arbitrarily arrest citizens in East African cities such as Nairobi. p'Bitek's focus on how the poor have historically been denied access to such public spaces within the urban environment is a harbinger of other calls for environmental justice by activists such as Wangari Maathai who would win the Nobel Peace Prize for her efforts.

Slow violence is also in evidence through the mental anguish that the prisoner experiences due to poverty. This is highlighted when the vagrant reflects on how his children are suffering from hunger and malnutrition.

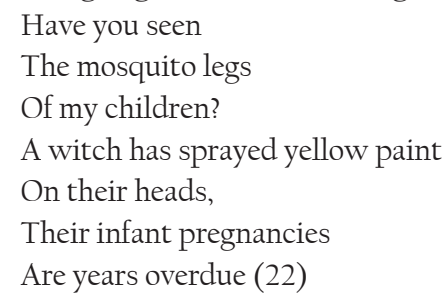

The mosquito, though a tiny insect, has been the cause of pain and suffering to Africans through the diseases it causes. The tiny legs of mosquitoes, when likened to those of the children of the prisoner, illustrate the extent to which the children are at a point that is close to starvation due to poverty. Yellow paint in this case symbolises the physical manifestation of the disease of Kwashiorkor which is a result of malnourishment. The children's hair has changed colour from black to yellow. The same relates to their distended bellies as a result of the disease. They are referred to as infant pregnancies. The fact that the prisoner and his family are suffering from malnutrition in the post-independence period indicates that the promises given at Uhuru such as the complete eradication of poverty, ignorance, and disease have not been fulfilled ten years after independence.

The vagrant recollects how he left his wife and children waiting by an empty pot for ingredients he had promised to bring back in order for a meal to be prepared, knowing full well that he had nothing to provide. This is why he left for the city park where he was arrested. He recalls how they could not even fall asleep even though they were tired, due to their hunger.

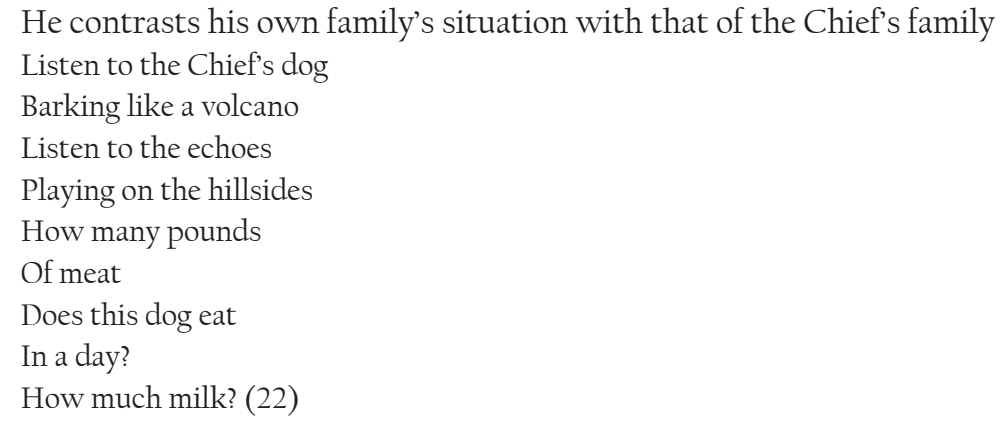

By using a simile that likens the barking of the chief's dog to the sound of a volcano's eruption, p'Bitek exploits hyperbole through the use of nature imagery to describe the powerful and energetic sound produced by the dog. When contrasted with the previous images of the weak and malnourished children, it paints a picture of an imbalanced society, whereby domestic animals belonging to the rich are well-fed whereas the masses have children that are suffering from hunger.

The use of anthropomorphic imagery in the verse could be interpreted using Evan Mwangi's prescription on the application of an African posthumanism related to Ubuntu, whereby "shared experiences of various marginalized groups [are presented] in ways that empower humans as well as animals" (31). Therefore, the illustration could read as expressing a desire for equity among both humankind and the domestic animals. This is further emphasised through the rhetorical question in which the plenitude of the dog's diet is contrasted with the scarcity in terms of nutritional calories that is manifested on the bodies of the vagrant's children. p'Bitek highlights class differences in independent East African society and places the responsibility for the prevailing situation at the door of leaders such as the Chief, who is depicted to be engaging in excessive consumption, whereas the masses lack access to basic nutrition.

The mental anguish the prisoner experiences is also captured in in section 5, which is titled "sacred rock". In this section, the prisoner, while still suffering from his physical injuries, is drawn to imagine that while he is 
incarcerated, a political leader has driven to his home in a Mercedes Benz, and taking advantage of his absence, is now making love to his wife.

Big chief

Is dancing my wife

And cracking

My sacred rock! (44)

This image of a sacred rock is part of the yonic imagery that is found within p'Bitek's poetry that may be derived from Acoli culture. Indeed, the word rock is also used as a euphemism for a woman's private parts in Song of Lawino (119). The sacred nature of the rock highlights the extent of the transgression being engaged upon by the political leader thus indicating the extent of the prisoner's frustrations with the actions of those in power against the helpless in society.

In the third section of the poem p'Bitek gives a historical background to the present predicament experienced by the vagrant. His present conditions are shown to be linked to a military takeover in which the vagrant's entire community was subjugated by repressive state authorities.

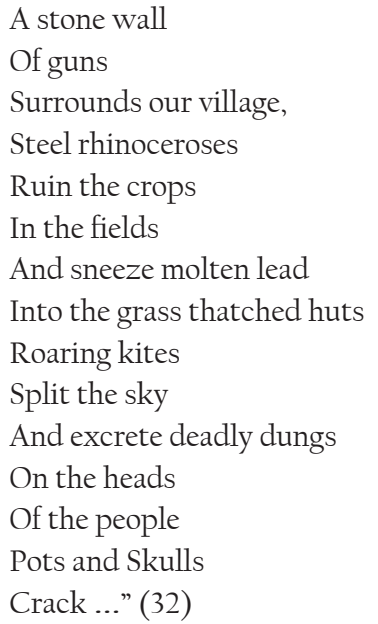

The use of metaphor in the above stanzas amplifies the dialectical construct that runs throughout the poem in terms of describing the present vis-à-vis the past. The new-fangled weapons that are used to take over the prisoner's village by state authorities such as guns, military tanks, and planes are defamiliarised through the point of view of a persona who cannot find adequate words in their own language to name them, and thus can only attempt to give them a description using nature imagery. Thus, guns are collectively seen as a concrete fortress just like the urban prison walls, and tanks are seen as steel animals which overrun the village farms and destroy produce. Jet fighters are seen as birds whose droppings as they fly overhead, kill people.

Through the use of this illustration, p'Bitek is giving the reader a description of the immediate effects of war on the environment. However, when contrasted with the current predicament of the prisoner, it becomes evident that the war that was carried out earlier continues to have an impact of slow violence to the prisoner and his community. The farms that the community relied on were destroyed during this war of occupation, which led to the vagrant and his family abandoning his village for the urban area.

This ties in with the illustration on Acoliland by Girling as mentioned above, and explains the vagrant's nostalgia for rural landscapes, as his migration was a result of displacement. The destruction of his immediate environment has led to his and his community's gradual impoverishment. Thus, from the above allegory, it is evident that the brutality that the prisoner is experiencing currently is as a result of a long and drawn-out historical 
process, affecting not only him as an individual, but his entire community. It thus explains his feelings of despair and helplessness as is demonstrated in his lament while taking a plea:

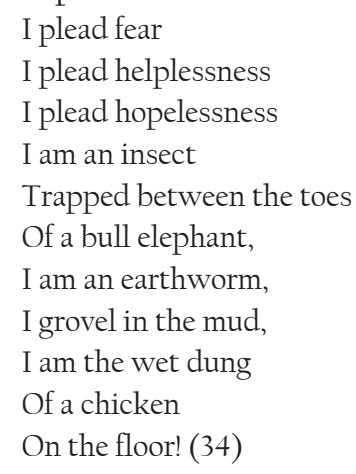

By describing himself as an "insect / trapped between the toes of a bull elephant", an earthworm grovelling in the mud, and the wet dung of chicken on the floor, the vagrant uses zoomorphic imagery to demonstrate his helplessness and unworthiness in the face of his mighty adversaries. A bull elephant would hardly notice or feel an insect trapped in its toes, an earthworm is helpless when trapped in mud, and wet dung of chicken on the floor is something that is indeed worthless.

The existential anguish felt by the prisoner and as expressed in the illustrations of his feeling of despair and helplessness in the face of might and power of the post-colonial state, is reason enough for a desire for revolution by the section of the population that feels that they are not provided with social security simply because they belong to a certain class or ethnic community. These long-term effects of such slow violence would concretise into what Nixon has described as structural violence in regard to the widening gap between the rich and the poor, and the creation of classes in society, primarily based on ease of access to State resources. In the case of East Africa, this is manifested through tribalism, clannism, and nepotism, a carryover from precolonial times into modernity that continues to affect East Africa to date.

The above is highlighted in section 4 and section 6 , in which the vagrant castigates the clans of his father and his mother respectively for contributing to his current predicament. Ofuani ("The Traditional and Modern Influences in Okot p'Bitek's Poetry") highlights some of the influences in p'Bitek's poetry: "p'Bitek's language and imagery are drawn from a whole range of Acoli song. The sources of influence include the satirical songs of the beer party, the victory songs of the bwola dance, the war songs, and the praise songs" (91, emphasis in original). The fact that the performance by the prisoner would not fit snugly into any of the categories of song described by Ofuani above, but instead stylistically and in terms of its function cuts across several types could be explained using an observation by Charles Okumu: "The oral literary features that Okot borrowed from Acoli traditional culture gave his poetry the distinctive song character that sets it apart from other written poetry. Nevertheless, Okot's songs can neither be sung nor fitted into the thematic classification of Acoli oral songs" (55).

It is clear that in these two sections in which the vagrant is condemning his parents, p'Bitek is borrowing from a cross-section of traditions, because there is evidence of the use of satire in the beer party songs, where by blaming his parents for his present condition, the vagrant is commenting on social evils in contemporary society, and by castigating his parents' respective clans, he is also using the bwola dance to condemn, rather than to praise leadership. Indeed, as is explained by p'Bitek, commoner clans that were not happy with their leadership under a chief traditionally had the right to leave and join another chiefdom ("Vernacular" 28), a desire the vagrant displays through his performance.

The vagrant thus castigates his father as follows:

You should have known

The Clan

In which the most Intelligent

Hardworking,

Thrifty

Ruthless

And most successful Chiefs

Are born and bred ... ! (36) 
The vagrant expresses his desire to make a bonfire of the bones of his father and grandfather once he leaves prison in order to avenge for their mistakes. His anger illustrates the situation in East Africa where people are prisoners of their ethnicity and their individual successes and failures are pegged on ethnic origins, which may provide access to state power, or otherwise. Merit is not considered.

The same argument is extended further in section 6, through an illustration of what happens in nature.

\section{A bird's song}

Breaks through the high ceiling

It is the ladybird

Collecting nectar

From the banana blossom

And flying back

To her nest

The chicks

Chip their thanks

In unison ... (49)

The bird identified as being the ladybird (a different connotation from the word's normal usage in English to refer to a specific type of insect), is captured in the activity of collecting nectar which it feeds to its nestlings. The environmental imagery is familiar to East Africans as pictures of the banana trees and the nectar collected therein by the ladybird are used. This illustration demonstrates to the reader how it is expected that parents will provide for their offspring, just like the bird takes care of its fledglings.

The vagrant proceeds in the section to castigate his mother for not having chosen a man from the "right" clan. He decries the fact that due to his birth, neither he nor his family will ever amount to anything

They describe my clansmen

As fools and weaklings,

Can you hear them saying

That my Clan

Will never rise to Power,

And I will die in deep poverty

And my children

Will become thieves? (53)

By describing the situation of this family, p'Bitek is highlighting the social evil of tribalism in East African society, which leads to the impoverishment of large sections of the population who are denied access to political and economic opportunities with ethnic identity predetermining social mobility.

Political violence by the state, on the other hand, is practiced at a more overt level, as is demonstrated in the poem. It is manifest on the site of the body, which directly receives the impact of this violence. This is demonstrated through the incarceration of the vagrant for frivolous reasons, and the physical violence meted out on him by state officials

Ten uniformed Stones

Break into my tiny hell,

Elephants trumpet

Rhinos scream

For blood

And charge,

The earth shakes her belly,

The walls jump

And dance

The stone floor

Urinates

Orgasm ... (30) 
We once again see an interplay between traditional and modern spaces, in which the modern period is represented by a harsh environment associated with concrete structures. In this case the prison guards are referred to metaphorically as uniformed stones, indicating the structural violence of State machinery in modern times. The physical violence the ten guards mete out on the prisoner is foreign to his world view and cannot be named directly, with the prisoner thus using animals such as Elephants and Rhinos to illustrate the severity of the beating that he receives from the prison guards.

In reading the nature imagery as presented in the first six sections of the poem, one establishes a history of the impact of modernity and the effects of the same on the vagrant's immediate environment. Colonial invasions are depicted to have led to environmental degradation and the displacement of people from the rural areas to urban areas. This in turn led to increased poverty and suffering during the post-colonial period, as is highlighted through the situation of the vagrant and his family.

\section{The assassin as a symbol of ethnic nationalism in East Africa}

The fact that section 7 introduces a new persona is evident through a change in the tone of the speaker. Whereas in the previous sections, the persona's tone indicated anger and helplessness due to poverty, in section 7, we come across a persona who is boisterous and titled, with an aggressive tone. Unlike the previous persona who felt helpless about the situation of the family he had left outside the prison walls, this prisoner seems to be confident that his family will see better days ahead.

Section 7 of the poem introduces us to this prisoner through a vignette.

The tiny Lagut bird

Carries a leaf of grass

To the olango thorn bush

To erect a hut

For her children

Who knock loudly

At the gate

And scream

To be let out (57, emphasis in original)

One can here identify Acoli names for fauna and flora through the species such as the Lagut bird and the Olango bush. The writer in using the Acoli words to identify plants and animals, domesticates the English language through poetry, and is a clear example of preserving the natural environment in discourse. This is in line with the suggestions by Gerald Moore cited above in regard to environmental literature. The illustration uses a scene taken from a familiar landscape, and an activity, whose nuanced meaning would be easily interpreted by East African readers.

In this vignette, we are presented with a bird that is working hard to fortify its nest so as to protect its fledglings from danger. The young ones, however, are in their innocence oblivious to the dangers that exist outside their confines and are thus always struggling to get out. Through this vignette, the prisoner is trying to tell the reader that some things are done for a people's own good, but through their ignorance or naivete, people generally fail to appreciate that fact. He is thus suggesting that whatever act he committed and led to his imprisonment had a utilitarian purpose that is yet to be appreciated by its beneficiaries.

The prisoner then follows this statement with a confident plea to his wife not to worry when she hears the news of his arrest. He is confident that he will access the best defence team, and that the African judges and those who hired him will ensure his release. The confidence the prisoner displays the concept of ethnicity in that the prisoner expects to receive a biased judgement simply because he comes from the same ethnic group with high 
authorities, within the judicial system. This also emphasises an idea of structural violence. The prisoner employs zoomorphic imagery in a quest to explain his action.

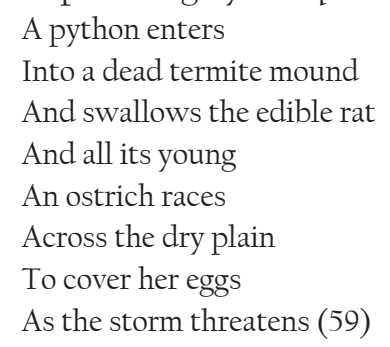

In this vignette, the image is given of a powerful animal (python) preying on a weaker species (edible rat) and consuming its entire family. This is contrasted with the image of a different species of animal (ostrich) dashing a long distance in order to defend its family from the dangers of rain. In this case, the poet is using images of the quest for survival in nature. Through this vignette, the persona is trying to explain that in nature, animals higher in the food chain are expected to prey on other, and also that instinctively, an animal will go to great lengths to protect their own. In essence, he seems to be defending violence as a way of attaining or preserving power, which is seen as naturally belonging to a certain group of people whose 'others' become mere victims. This illustration indicates how the kind of violence that is observed in postcolonial society is more as a result of ethnic nationalism which arises through a desire to attain or perpetuate access to state resources by a small number of people.

The prisoner then goes on to imagine the future prospects for his family. Unlike the vagrant, who was poor and hopeless, this new prisoner has just acquired a large farm and a better house than the one they currently live in which is a thatched hut. Unlike the vagrant before him, who when thinking of his wife was deeply concerned that his incarceration would lead to her exploitation by the big Chief, the present prisoner displays optimism in that he expects his own wife's new bed to be as soft as the voice of a dove (title of the section).

In section 8 we are provided with a background as to the reason for the arrest of the prisoner. The section titled "distant echoes" opens with a vignette that describes another situation of conflict in nature:

The lek lizard

Wields his deadly tongue

And smashes a mosquito

To death...

There are tears of joy

In his eyes! (65, emphasis in original)

The vignette gives a portrait of a situation in which a lizard captures an insect, and the satisfaction that it derived from the action. The action of the lizard shooting out its tongue to capture the insect could be likened to that of a bullet flying out of a gun and hitting its target. Both events happen extremely fast, within the blink of an eye. Once again, the Acoli word for the particular species of lizard is used in order to preserve African nature even in poetry written in English. Through this vignette the reader is informed that the prisoner is an assassin. The fact 
that he relishes the fact that he killed a fellow human being, is also an aspect of this prisoner's character that is highlighted through the imagery used. The prisoner indicates that his victim was one of the country's leaders.

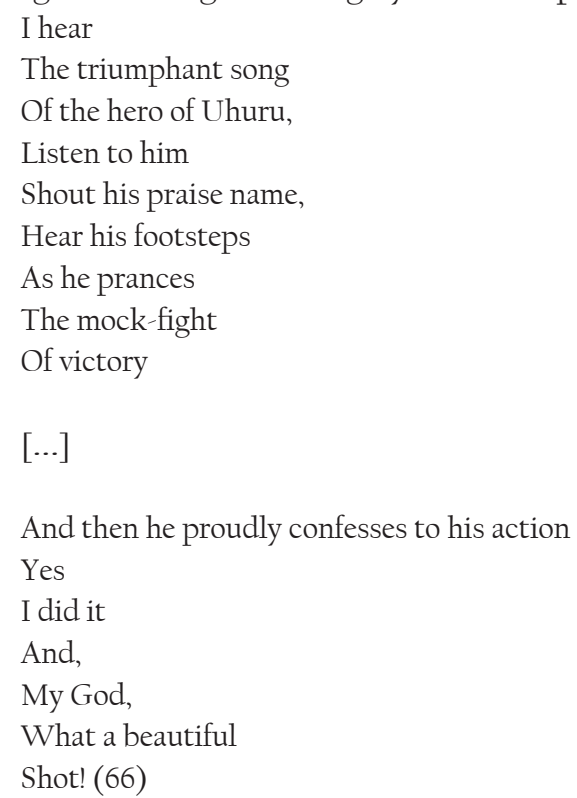

The tone of satisfaction by the prisoner as he describes the murder of a leader who had led his country to independence demonstrates his arrogance. He tries to argue that he did it for his country, and not for money, which contradicts the situation described in the previous section, where the prisoner was gladly announcing to his wife that they would have a better life thanks to the things he had bought his family with the money he had been paid for the assassination.

He heaps all manner of evil on the leader he assassinated in order to justify his actions.

He was a traitor

A dictator

A murderer

A racist

A tribalist

A clannist

A brotherist ...

He was corrupt

A reactionary

A revisionist

A fat black capitalist

An extortioner

An exploiter ... $(67,68)$

Having given reasons for the actions he took, which he deems heroic, the prisoner expresses his surprise that the prison warders are subjecting him to beatings instead of showering him with accolades, which reveals treachery and betrayal, even among the ruling classes.

In section 9, the political assassin explains his actions to the assassinated leader's widow, saying the dead leader had also created several widows in his turn, who were suffering just like she is. He asks her to instead be thankful to him for liberating the land from an oppressor and also for making her famous. An important aspect in regard to African ecocriticism to mention at this point is how elements such as conscience, health, and sanity are deemed as part of the external environment that would impinge on the self from outside in the African worldview, unlike in the Western worldview which would see them as being part of one's own consciousness. This is a point that is argued out by p'Bitek in "The Self in African Imagery", which was published in Africa's Cultural Revolution. p'Bitek likens this idea to the Christian belief that the transformation of a person's character through salvation 
comes from an external source other than the self. This observation goes a long way in illustrating Wu's explanation on African ecocriticism using Chinua Achebe's Things Fall Apart (1958):

An emphasis on the environmental perspective of Achebe's novel reminds us that the challenge of locating environmental issues in African literature lies in the fact that they may not look like environmental issues, as addressed or represented in Anglo-American environmental literature. In the case of Achebe's novel, the environment refers to the Igbo land as a whole - composed of the inhabitants, the gods and ancestral spirits they worship, the village compounds, as well as the forests surrounding the community (142, emphasis in original).

The same idea emerges in section 10. The section is titled "killer mark", indicating how the act of killing a fellow human being has gradually started weighing upon the prisoner's conscience. By this time, the political assassin's tone seems to be changing. He is now desperate to be let out of prison. He is pleading with his gaolers to release him so that he may go out and till his land, and plant millet. He expresses a desire to go to church to confess his sins, and then visit the village in order to be ritually cleansed from the act of murder.

The political assassin expresses a desire to be rid of his sin through the Christian church, in order to assuage his guilty conscience. At the same time, he would like to visit the village in order to engage in sacrifices and rituals that would cleanse him from attack by external forces in the environment such as the vengeful ghost of the person that he killed. By placing the procedures of these separate actions side by side in the verse, p'Bitek illustrates how the killer mark is seen to be coming from two sources: the assassin's conscience in the Western (Christian) view, and external environment in the African traditional view. The fact that this prisoner has incorporated both the traditional and Western outlook in terms of religion, demonstrates that he belongs to a new emerging class of Africans who express a duality in terms of their medico-religious activities.

The duality in the political assassin's world view could also be interpreted as a sign of his unstable nature. He is depicted as being an opportunist with no real political convictions. Indeed, as Ojaide observes of this prisoner: "[He] does not deserve the cloak of heroism he fantasizes as rightly belonging to him" (381). The fact that he practices the same, or even worse social evils that he blames the leader whom he assassinated of undertaking is quite telling. He was corrupted by being paid to kill a political leader, he relies upon ethnicity to get acquitted for actions that are against the law, and he arrogantly demands respect from the prison warders whom he now views as belonging to a lower social class than he does, due to what he imagines to be his new social status.

Through examining nature imagery in sections 7 through to section 10, it is evident that p'Bitek exploits images of conflict and survival in the animal world to present us with the history of a prisoner who is an assassin. Through his depiction of the assassin, p'Bitek indicates his suspicion of the nationalism practiced in the modern States in East Africa, where coups and counter coups were staged and political assassinations carried out, ostensibly to ensure a better life for all, but in reality, as a design to perpetuate the same narrow interests of an elite that pursues structural violence. This is made quite evident through the fact the assassin is abandoned by those who hired him, and he ends up expressing the fear that he may be hanged.

\section{The minister and the nature of corruption in East Africa}

The third persona that we come across in the poem. Is introduced in section 1l. Once again, the reader experiences a change in tone when they come across this new persona. The arrogance and then incremental fear of the previous persona have now been replaced by a tone that exudes confidence and relative calm. This tone is complemented by the illustrations presented through zoomorphic imagery.

\section{Shhhhh!}

Listen,

Listen to the millipede

Whispering a lullaby

To her newly hatched

baby,

Do not make noises,

Do not disturb

The sleeping one! (81).

The portrayal of a millepede taking care of her newly hatched baby is a regal image derived from the natural environment. According to Acoli indigenous knowledge, the millipede or Kolok, is one of the macro-organisms whose 
presence, when observed, is an indication that land is suitable for farming (Nuwategeka 105). Also, the millipedes as presented are neither in conflict, nor are they struggling for survival. Instead, they are depicted in the process of regeneration. The introduction of this type of image as well as the change in tone provides a sharp contrast to the earlier images of tension between species that were evident in the previous sections in which the persona of the assassin was depicted.

The reason for the change in the type of imagery used becomes evident in the lines that follow

Stop it.

Stop it.

I am a Minister,

Do you not know me? (82)

It is thus revealed that the persona is indeed a state minister. He is shocked that despite his having appeared on television, his voice being recognisable from news broadcasts and his pictures featuring prominently in newspapers, the prison warders are still subjecting him to beatings and ignoring his command. The reasons for his incarceration are revealed through a vignette that presents the reader with a scene derived from the use of nature imagery.

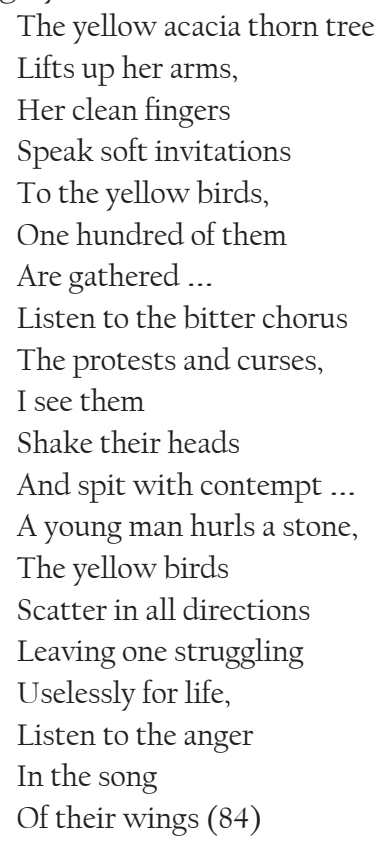

The yellow acacia thorn tree is used symbolically to represent an assembly where politicians meet. This could either be a parliament, or a cabinet of ministers. The yellow birds are the politicians who are gathered in the assembly. These politicians are all birds of a feather, and thus flock together. While unanimous in their actions, only one falls victim to the metaphoric stone, which could be interpreted as an action taken against these politicians to expose either corruption or any other element of abuse of office practiced in most East African governments that are responsible for underdevelopment and the impoverishment of the masses in the post-colonial period. Although the rest go scot free, they are neither innocent nor remorseful as is indicated through the anger displayed as the birds take flight.

It becomes clear how the minister ended up in prison. He was unfortunate enough to be singled out in a scandal that is most likely linked to corruption. He then tries to resort to ethnicity in a bid to get help from powerful members of his community such as the chief of the army and his brothers in the army and the police, to help him in his quest to be released from jail, just like was the case with the assassin before him. This further illustrates the aspect of structural violence within the state apparatus that promises a soft landing to criminals who belong to certain sections of society.

Unlike the other prisoners before him, the minister is so rich that rather than worry about the well-being of the family that he has left outside the prison walls, he wants to write letters and send money to his children and 
his parents. His only worry is that they might find out that he has been incarcerated. He does not suffer the existential anguish felt by the vagrant who was worried about the plight of the children he had left behind. Indeed, this prisoner's situation seems to be but a temporary setback, indicating how whereas the poor in East Africa suffer for no reason, the wealthy and those in power easily get away with more serious crimes. With the exposition of the third prisoner and his situation, p'Bitek exhausts his depiction of issues pertaining to the past and present in society as is presented through Song of Prisoner.

In sections 11 and 12 the poem reveals issues of class differences and corruption in modern day society through the persona of the minister.

\section{The composite prisoner and a vision for a future East African society}

In Uhuru's Fire, Roscoe writes about the subtleties of time in relation to Song of Lawino. Quoting John Mbiti, he indicates that in the traditional African worldview, the concept of time is seen through a long past, a present, and hardly any future (41). Roscoe uses this to argue that Lawino is more interested in the past and present than in the future. In Prisoner, however, p'Bitek does bring in the idea of a future. Having illustrated Africa's pristine past through the use of nature imagery and contrasting it with a desolate present through the depiction of the urban jail, p'Bitek then goes on to imagine a future in which the prisoners dream about the kind of society that they would like to live in. This is evident in the poem from section 12 through to section 15 . There is dancing and singing in the poem at this point, which is reminiscent of the Heias in Aimé Césaire's Cahier d'un retour au pays natal (1939).

In order to depict this yearning for a brighter future, p'Bitek now resorts to the use of a composite prisoner. This prisoner takes stock of the situation he finds himself in and realises that the failure of the dreams of Uhuru were an actual form of imprisonment that exists in East Africa even outside the physical prison walls. In other words, East African society is under the arrest of a multitude of social vices that have imprisoned the dreams of Uhuru. In section 12, therefore, we see how the prisoner yearns for youthful fresh air. The prisoner wishes to commune with people from all classes and all walks of life. This is expressed through his yearning to visit all the different geographical locations of his country. He wants to indiscriminately taste all the alcoholic beverages on offer in the world, and commune with people from all races and tribes. This could be seen as a wish for a future without the structural and political violence of the State and the slow violence of environmental degradation, that has imprisoned East Africa, and a yearning for equality all over the world. This utopian dream is also expressed in Section 14, with the prisoner wishing that the steel gates that imprison him would be opened, so that he could join in all the dances in the world. He wants to dance so that he forgets that his children will remain poor even in this independent society. The poem closes in section 15, with the prisoner still expressing his wish to commune with the entire world through their dances as a way to forget his present predicament.

Atieno-Odhiambo et al. misread the dancing and drinking described in the poem as a sign of hopelessness. They are in fact a sign of hope for a future East African society that could be interpreted as a call for unity in order for society to pull away from the chains of ethnic and class divisions. This indeed is the desire of the composite prisoner. p'Bitek through this prisoner, indicates to East Africans reading the poem, that even without the physical walls around them, they too are prisoners of their own proclivities which have led them to commit social evils, and that the only way to a better future for the entire society, is through liberating oneself, and having individuals seeing themselves as part of a unified whole, and together, as part of the global community.

Indeed, this yearning for equality for all and communing with all including nature, as the aspiration of the composite prisoner could be read as a prescription by p'Bitek for the kind of ethical position needed in East African society if it were to escape from the clutches of modernity and neo-colonialism. His ethical position could then be said to fit in with the kind of posthumanism prescribed by Evan Mwangi, which "includes the human, nonhuman, nonhuman animals, and the planet as a whole" (19).

My reading has revealed three personae in the present moment, and a composite prisoner drawn from the three personae in the sections that indicate the desire for a future East Africa. Past readings have indicated some confusion in this regard, with different critics interpreting various numbers of persona(e) (Atieno-Odhiambo et al.; Ofuani, "Digression as Discourse Strategy in Okot p'Bitek's Dramatic Monologue Texts"), others suggesting the existence either of a composite prisoner (Wanambisi; Mweseli) or a choral of prisoners (Heywood) or a soliloquy by a schizophrenic prisoner (Ogunyemi). It was therefore important that I revisit this aspect of the poem and 
provide evidence through the use of nature imagery to arrive at the meaning of the poem in a manner that clarifies the number of personae involved in the poem.

\section{Conclusion}

Writing in the wake of independence, Okot p'Bitek uses his poem Song of Prisoner to point out the pitfalls in society that have led to the death of the dreams of Uhuru which were the eradication of poverty, disease, and ignorance. Having pointed out these pitfalls of modernity, he prescribes a way for East Africans to move forward by liberating themselves from these social evils. His text is thus still relevant today as the evils he pointed out fifty years ago are still prevalent in East African society today. We could therefore establish that Okot p'Bitek portrays a revolutionary affirmative consciousness in his writing of the poem Song of Prisoner.

In signalling the vehicle and the tenor of the metaphors identified through the use of nature imagery in Song of Prisoner, this article has exploited an African approach to ecocriticism not only to demonstrate how p'Bitek preserves East Africa's natural environment in Song of Prisoner, but also to show how p'Bitek provides a commentary on his society and the intricate relationships between people in this society. The paper also demonstrates how Okot p'Bitek suggests that the existing political and economic problems could be solved through the abolition of social ills such as tribalism and corruption.

\section{Works Cited}

Akutekha, Pritt. "The Status of Vagrancy Act in Independent Kenya: A study of a Constitutional Dilemma in a Neo-Colonial Economy.” LL. B. Dissertation. U of Nairobi, 1977.

Atieno-Odhiambo, A. et al. "Atieno-Odhiambo, Aloo Ojuka, Margaret Marshment and George Heron: Okot's Two Songs: A Discussion." Standpoints on African Literature, edited by Chris L. Wanjala. East African Literature Bureau, 1973, pp. 96-146.

Brown, Stuart C. "I. A. Richards' New Rhetoric: Multiplicity, Instrument, and Metaphor." Rhetoric Review vol. 10, no. 2, 1992, pp. 218-31. DOI: https://doi.org/10.1080/07350199209388966.

Caminero-Santangelo, Byron \& Garth A. Myers. "Introduction." Environment at the Margins: Literary and Environmental Studies in Africa, edited by Byron Caminero-Santangelo \& Garth A. Myers. Ohio U P, 2011, pp. 1-21.

Caminero-Santangelo. Different Shades of Green: African Literature, Environmental Justice and Political Ecology. U of Virginia P, 2014.

Césaire, Aimé. Cahier d'un Retour au Pays Natal. Présence Africaine, 1983.

Coetzee, J. M. Life e Times of Michael K. Viking, 1983.

Deloughrey, Elizabeth, Renée K. Gosson \& George B. Handley. "Introduction." Caribbean Literature and the Environment: Between Nature and Culture, edited by Elizabeth Deloughrey, Renée K. Gosson \& George B. Handley. U of Virginia P, 2005, pp. $1-30$.

Fassin, Didier. "The Trace: Violence, Truth, and the Politics of the Body." Social Research vol. 78, no. 2, 2011, pp. 281-98.

Girling, Frank. "The Acholi of Uganda." Okot p'Bitek, Frank Knowles Girling Lawino's People: The Acholi of Uganda, edited by Tim Allen. LIT Verlag, 2019, pp. 47-358.

Heywood, Annemarie. "Modes of Freedom: The Songs of Okot p'Bitek." Présence Africaine vol. 1, no. 113, 1980, pp. 235-57. DOI: https://doi.org/10.3917/presa.113.0235.

Huggan, Graham \& Helen Tiffin. "Postcolonial Ecocriticism: A Reflection on the Scenic Apertures of Mount Fako in Cameroon.” ISLE vol.17, no. 4, 2010, pp. 792-6. . Postcolonial Ecocriticism: Literature, Animals, Environment. Routledge, 2010.

Maathai, Wangari M. Unbowed: A Memoir. Anchor, 2007.

Macgoye, Marjorie O. Make it Sing and Other Poems. East African Educational, 1988.

Mack, Beverly B. "Metaphor is a Bridge to Ultimate Reality: Metaphor in Hausa Women's Poetry." Research in African Literatures vol. 37, no. 2, 2006, pp. 43-60. DOI: https://doi.org/10.2979/ral.2006.37.2.43.

Moolla, Fiona, ed. Natures of Africa: Ecocriticism and Animal Studies in Contemporary Cultural Forms. Wits U P, 2016.

Moore, Gerald. "Literature and Environment in East Africa." East Africa's Cultural Heritage, edited by Mbiyu Koinange. East African P House, 1966, pp. 109-14.

Mwangi, Evan. The Postcolonial Animal: African Literature and Posthuman Ethics. U of Michigan P, 2019.

Mweseli, Monica. A Study of Okot p'Bitek's Poetry. Africawide Network, 2005.

Nichols, Lee. Conversations with African Writers. Voice of America, 1981.

Nixon, Rob. Slow Violence and the Environmentalism of the Poor. Harvard U P, 2011.

Nuwategeka, Expedito \& Martine Nyeko. "Indigenous Land Suitability Evaluation System of the Acholi tribe of Northern Uganda." Journal of Agricultural Extension and Rural Development vol. 9, no. 5, 2017, pp. 97-110.

Ofuani, A. Ogo. "The Traditional and Modern Influences in Okot p'Bitek's Poetry." African Studies Review vol. 28, no. 4, 1985, pp. 87 -99. DOI: https://doi.org/10.2307/524525. . "Digression as Discourse Strategy in Okot p'Bitek's Dramatic Monologue Texts." Research in African Literatures vol. 19, no. 3, 1988, pp. 312-40.

Ogunyemi, Chikwenye O. "The Song of the Caged Bird: Contemporary African Prison Poetry." Ariel: A Review of International English Literature vol. 13, no. 4, 1982, pp. 65-84.

Ojaide, Tanure. "Poetic Viewpoint: Okot p'Bitek and His Personae." Callaloo no. 27, 1986, pp. $371-83$. 
Okumu, Charles. “The Form of Okot p'Bitek's Poetry: Literary Borrowing from Acoli Oral Traditions." Research in African Literatures vol. 23, no. 3, 1992, pp. 53-66.

Owuor, Yvonne A. Dust. Granta, 2014.

P'Bitek, Okot. Africa's Cultural Revolution. Macmillan, 1973.

"Future of the Vernacular Literature." East Africa's Cultural Heritage, edited by Mbiyu Koinange. East African P House, 1966. pp. 70-7.

. Song of Lawino and Song of Ocol. East African Educational, 1989.

, Two Songs. Heinemann, 1971.

, Wer pa Lawino. East African P House, 1969.

Roscoe, Adrian. Uhuru's Fire: African Literature East to South. Cambridge U P, 1977.

Rueckert, William. "Literature and Ecology: An Experiment in Ecocriticism." The Ecocriticism Reader: Landmarks in Literary Ecology, edited by Cherryll Glotfelty and Harold Fromm. U of Georgia P, 1996. pp. 105-23.

Taoua, Phyllis. "The Postcolonial Condition." The Cambridge Companion to the African Novel, edited by Abiola Irele. Cambridge U P, 2009. pp. 209-26.

Vital, Anthony. "Toward an African ecocriticism: Postcolonialism, ecology, and Life e Times of Michael K." Research in African Literatures vol. 39, no. 1, 2008, pp. 87-106. DOI: https://doi.org/10.2979/ral.2008.39.1.87.

Wanambisi, Monica N. Thought and Technique in the Poetry of Okot p'Bitek. Vantage, 1985.

Wu, Chengyi C. "Towards an Ecocriticism in Africa: Literary Aesthetics in African Environmental Literature." Natures of Africa: Ecocriticism and Animal Studies in Contemporary Cultural Forms, edited by Fiona Moolla. Wits U P, 2016. 